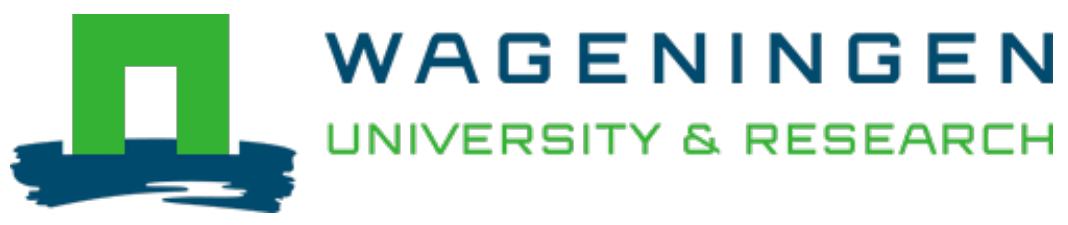

\title{
Lipid and protein changes during the ensilage of blue whiting (Micromesistius poutassou Risso) by acid and biological methods.
}

\author{
Food Chemistry \\ Lurdes Enes Dapkevicius, M.; Batista, I.; Nout, M.J.R.; Rombouts, F.M.; Houben, J.H. \\ https://doi.org/10.1016/S0308-8146(97)00156-8
}

This publication is made publicly available in the institutional repository of Wageningen University and Research, under the terms of article $25 \mathrm{fa}$ of the Dutch Copyright Act, also known as the Amendment Taverne. This has been done with explicit consent by the author.

Article 25 fa states that the author of a short scientific work funded either wholly or partially by Dutch public funds is entitled to make that work publicly available for no consideration following a reasonable period of time after the work was first published, provided that clear reference is made to the source of the first publication of the work.

This publication is distributed under The Association of Universities in the Netherlands (VSNU) 'Article $25 \mathrm{fa}$ implementation' project. In this project research outputs of researchers employed by Dutch Universities that comply with the legal requirements of Article $25 \mathrm{fa}$ of the Dutch Copyright Act are distributed online and free of cost or other barriers in institutional repositories. Research outputs are distributed six months after their first online publication in the original published version and with proper attribution to the source of the original publication.

You are permitted to download and use the publication for personal purposes. All rights remain with the author(s) and / or copyright owner(s) of this work. Any use of the publication or parts of it other than authorised under article $25 \mathrm{fa}$ of the Dutch Copyright act is prohibited. Wageningen University \& Research and the author(s) of this publication shall not be held responsible or liable for any damages resulting from your (re)use of this publication.

For questions regarding the public availability of this publication please contact openscience.library@wur.nl 


\title{
Lipid and protein changes during the ensilage of blue whiting (Micromesistius poutassou Risso) by acid and biological methods
}

\author{
Maria de Lurdes Enes Dapkevičius, ${ }^{a}$ Irineu Batista, ${ }^{b}$ M. J. Robert Nout, ${ }^{a \star}$ Frank M. Rombouts ${ }^{a}$ \\ \& Jacques H. Houben ${ }^{c}$
}

${ }^{a}$ Department of Food Science, Section of Food Chemistry, Microbiology and Hygiene, Wageningen Agricultural University, Bomenweg 2,6703 HD Wageningen, The Netherlands

${ }^{b}$ Instituto de Investigação das Pescas e do Mar. Departamento de Valorização dos Produtos Marinhos, Avenida de Brasília. 1400 Lisboa, Portugal

${ }^{c}$ Department of the Science of Food of Animal Origin. Faculty of Veterinary Medicine, Utrecht University, Yalelaan 2, 3508 TD Utrecht, The Netherlands

(Received 12 March 1997; revised version received 7 June 1997; accepted 27 June 1997)

\begin{abstract}
Fish waste is a potential source of protein for animal nutrition. Ensilage could provide an advantageous means of upgrading these residues. Careful control of the degree of proteolysis and lipid oxidation is required to produce silages of high nutritional value. This paper studies the changes in lipids and protein during storage ( 15 days) of acid silages (with $0,0.25$ and $0.43 \%, w / w$, of formaldehyde) and biological silages (with 10 and $20 \%$ molasses or dehydrated whey) prepared from blue whiting. A remarkable reduction in protein solubilisation values was achieved by adding formaldehyde. However, formaldehyde addition led to an increase in the peroxide value of the oil extracted from the silages. Ensiling by biological methods seems promising. It yielded both a considerable reduction in protein solubilisation and in basic volatile nitrogen when compared with acid ensilage. In addition, the oil from biological silages had lower peroxide values than the oil from acid silages with added formaldehyde. (C) 1998 Elsevier Science Ltd. All rights reserved.
\end{abstract}

\section{INTRODUCTION}

Industrial processing of fish for human consumption yields around $60 \%$ by-products and only $40 \%$ edible flesh (Raa and Gildberg, 1982). Fish residues can be advantageously upgraded by conversion into fish silage; this approach is more friendly towards the environment, safer, technologically more flexible and economically more efficient than manufacturing fish meal (Raa and Gildberg, 1982).

Fish silage can be produced by two methods: direct addition of acid (acid-preserved fish silage) or fermentation with lactic acid bacteria (biological fish silage). Both types of silage can be used as nutritive supplement in animal feeding. Biological fish silage has been shown to have a good nutritional value (Kompiang et al., $1980 a$ ), significantly better than the acid fish silage (Kompiang et al., 1980a,b).

Fish silage is a promising product that has already found some industrial application (Espe et al., 1992a)

*To whom correspondence should be addressed. and its use can become widespread. The presence of oil with high levels of polyunsaturated fatty acids (PUFA), thus very prone to oxidation, is one of the constraints for its broad use in animal feeding. Oil retained in fish silage can become oxidised, rendering the feed unpalatable or unsafe to livestock (Haard et al., 1985). Several antioxidants have been used to prevent deterioration of the lipid fraction of the silages (Machin et al., 1990; Espe et al., 1992a,b). De-oiling is also possible and may be desirable (Potter et al., 1980). Formaldehyde can contribute to the inhibition of lipid oxidation in acidpreserved fish silages (Haard et al., 1985) and its content was found to decrease during the storage of fish (Lovern, 1965). Lactic acid fermentation has a beneficial effect on the lipids in fish silage, stabilising the oil and improving its acceptability in animal diets (Raa and Gildberg, 1982).

During ensilage, autolysis takes place and the fish gradually liquefies as the protein matrix partially solubilises due to its breakdown by endogenous enzymes (Raa and Gildberg, 1982). The autolytic activity occurring during the ensilage of fish leads to an increase in the 
concentrations of ammonia, amines, amino acids and peptides (Haard et al., 1985). Up to $90 \%$ of the organic nitrogen becomes solubilised in acid-preserved fish silages (Haard et al., 1985), whereas ensiling by the biological method yields solubilisation values of around 60-70\% (Hassan and Heath, 1986, 1987; Lindgren and Pleje, 1983).

Feeding trials performed on several species of monogastric animals showed that it might be advantageous to have some pre-digested protein in the diet, but there is a limit over which the animals would have difficulties in using the absorbed protein for synthetic purposes (Espe et al., 1992a). However, no decreases in weight gains were observed when chickens were fed diets in which autolysed fish silages contributed up to $400 \mathrm{~g} \mathrm{~kg}^{-1}$ of the total dietary protein (Espe et al., 1992a).

The degree of hydrolysis of the protein in a fish silage is likely to result in a lower nutritive value for ruminant livestock. The small peptides and amino acids formed during ensilage are more readily available to the ruminal microflora. When metabolised by the microflora in the rumen, the efficiency of nitrogen utilisation by the animals can decrease and toxicity problems can occur, particularly when the animal is on a low energy diet (Ørskov, 1977). The lower degree of hydrolysis in biological fish silages can, thus, for these animals, be regarded as advantageous from the nutritional point of view.

When applied to soybean oil-meal, formaldehyde increased the flow of dietary amino acids in the intestine of adult ruminants by $50-90 \%$ (Verite et al., 1977). A commercial mixture containing formaldehyde is available as an additive for ensiling grass (Delort-Laval, 1985). Relatively low concentrations of formaldehyde were found to be sufficient to arrest protein hydrolysis in acid-preserved and biological fish silages (Haard $e t$ al., 1985; Fagbenro and Jauncey, 1994). This finding is important, since undesirable side effects of excessive formaldehyde in ruminant rations, such as decrease in voluntary intake and loss in the efficiency of utilisation of dry matter, fibre and nitrogen can occur (Haard et al., 1985).

The present work aims at comparing the effects on the nitrogen fraction and on the lipids of blue whiting (Micromesistius potassou Risso) of ensiling by acid or biological methods. Formaldehyde addition is tested in the acid-preserved silages as a means of controlling lipid and protein degradation and two carbohydrate sources (molasses and dehydrated whey) are used for the preparation of biological fish silages.

\section{MATERIALS AND METHODS}

\section{Preparation of the silages}

Blue whiting (Micromesistius poutassou Risso) was caught near the Portuguese coast by the research ship of the Portuguese Institute for Fisheries and Marine Research, Lisbon, and kept frozen in plastic containers $\left(-28^{\circ} \mathrm{C}\right)$ for several months. Prior to ensiling, the fish was thawed overnight at ambient temperature and minced in a Hobart meat grinder. The additives were incorporated using a kneading machine. Three-kilogram batches of several types of silages were prepared, according to the formulas described in Table 1.

The silages were stored in plastic bags at ambient temperature $\left( \pm 20^{\circ} \mathrm{C}\right)$ during the 15 days of the experiment.

Formaldehyde was added as formalin (SIGMA, 37\% formaldehyde).

Dehydrated whey was obtained from a dairy plant (Lacto-Açoreana, Azores, Portugal) and sugar beet molasses from a sugar plant (SINAGA, Azores, Portugal). The dehydrated whey contained $3 \%$ moisture, $1.5 \%$ fat, $11.5 \%$ protein, $75 \%$ lactose and $9 \%$ ash. A $10 \%$ solution of dehydrated whey had a $\mathrm{pH}$ of $6.0-7.0$.

The starter used was prepared by inoculating a ground, cooked fish/molasses/water mixture (55:20:15, $\mathrm{w} / \mathrm{w} / \mathrm{w})$ with $10 \%(\mathrm{w} / \mathrm{w})$ of a Lactobacillus plantarum MRS broth culture and incubating the mixture for $72 \mathrm{~h}$ at $35^{\circ} \mathrm{C}$. After incubation, the mixture had a pH of 4.19. The $L$. plantarum culture available at the Portuguese Institute for Fisheries and Marine Research had been in use in olive fermentation. It was subcultured three times in MRS broth prior to use.

\section{Analytical determinations}

Moisture, crude protein, crude fat and ash were determined by standard procedures (AOAC, 1984). For the determination of $\mathrm{pH}$ values, $5 \mathrm{~g}$ of sample were homogenised with $50 \mathrm{ml}$ distilled water and measurements were made with a combined glass calomel electrode. Viscosity was determined with a synchro-lectric viscometer (model LVF, Brookfield Engineering Laboratories, Inc., UK). Non-protein nitrogen (NPN) was determined by the micro Kjeldahl method in trichloroacetic acid $(7 \%)$ extracts of the silages and in extracts of fresh, ground fish. Total volatile basic nitrogen (TVBN) was determined by the microdiffusion method of Conway (Anon., 1988). For the determination of amino acids, well homogenised samples of silages and fresh, ground fish were hydrolysed in $6 \mathrm{~N} \mathrm{HCl}$ at $110^{\circ} \mathrm{C}$ for $24 \mathrm{~h}$. After removing the acid by means of evaporation in a rotovapor, a known volume of sodium citrate buffer ( $\mathrm{pH} \mathrm{2.2)} \mathrm{was} \mathrm{added} \mathrm{and} \mathrm{the} \mathrm{samples} \mathrm{were}$ filtered through Millipore membranes (USA) with pores of $0.22 \mu \mathrm{m}$. The samples were then injected into an amino acid analyser (Alpha 4150-LKB, Biochrom, Sweden), equipped with an integrator. The peroxide value of oil extracted from freshly ground fish and from silage samples was determined iodometrically, according to a standard procedure (AOCS, 1993). For the extraction of the oil, the method of Bligh and Dyer (1959) was used. All determinations were made in duplicate. 
Table 1. Formulas for the preparation of acid and biological silages from blue whiting (Micromesisitius poutassou Risso)

\begin{tabular}{lll}
\hline Designation & Composition & Proportions (on a weight basis) \\
\hline AS 0 & Ground raw fish + formic acid & $97: 3$ \\
AS F0.25 & Ground raw fish + formic acid + formaldehyde & $96.75: 3: 0.25$ \\
AS F0.43 & Ground raw fish + formic acid + formaldehyde & $96.57: 3: 0.43$ \\
BS M10 & Ground raw fish + molasses + water + starter & $55: 10: 15: 20$ \\
BS M20 & Ground raw fish + molasses + water + starter & $45: 20: 15: 20$ \\
BS W10 & Ground raw fish + dehydrated whey + water + starter & $55: 10: 15: 20$ \\
BS W20 & Ground raw fish + dehydrated whey + water + starter & $45: 20: 15: 20$ \\
\hline
\end{tabular}

\section{RESULTS AND DISCUSSION}

\section{Proximate composition}

Table 2 shows the proximate composition of the different silages at the beginning and the end of the experimental period.

A slight increase in moisture during fermentation was observed for the biological silages. This could be a result of the microbial activity within the silages. The increases in fat and protein proportions in the dry matter of biological silages during storage can be explained by the utilisation of carbohydrates during the fermentation process.

The differences in composition observed for the acid fish silage are not easy to interpret. Formaldehyde addition to fish brings about considerably complex changes. Proteins tend to aggregate and lose solubility, mainly due to the formation of noncovalent bonds among molecules (Ang and Hultin, 1989; Owusu-Ansah and Hultin, 1987). The amount of total lipids decreases, hydrolysis occurs in the neutral lipid, esters of stearic acid and phospholipid fractions, whereas the proportion of lipid-protein complexes increases in fish preserved by formaldehyde (Ostyakova and Kosvina, 1975). The low values of crude fat in the silage with $0.25 \%$ formaldehyde could result from the degradation of lipids. The concentration of crude fat in silages with $0.43 \%$ added formaldehyde is higher than in the acid silage without formaldehyde. A possible explanation for this might be the increased formation of lipid-protein complexes that the fat extraction method used would not be able to disrupt completely.

\section{Viscosity}

The formaldehyde-treated silages did not liquefy during the observation period. For this reason, their viscosity was not measured. The viscosity values represented in Fig. 1 concern only the acid silage with no formaldehyde added and the biological silages. The liquefaction of the silages is completed early in the process, normally within the first two or three days. Biological silages prepared with the addition of dehydrated whey liquefied somewhat less than the other silages.

\section{Changes in pH}

The evolution in $\mathrm{pH}$ values after 15 days for the acid and biological fish silages is shown in Fig. 2. The final values obtained for the acid and biological silages differ considerably. It should be kept in mind, however, that the acid responsible for preservation is not the same in both cases, and that the $\mathrm{pKa}$ of the preservative acid determines the $\mathrm{pH}$ the silages should reach to be stable (Raa and Gildberg, 1982). The values reached in the acid silages in this experiment are within the range of acceptability (Raa and Gildberg, 1982). For biological

Table 2. Proximate composition of blue whiting (Micromesisitius poutassou Risso) before and after ensilage by different methods

\begin{tabular}{|c|c|c|c|c|c|}
\hline Sample* & $\begin{array}{l}\text { Storage time } \\
\text { (days) }\end{array}$ & $\begin{array}{c}\text { Moisture } \\
\left(\mathrm{g} 100 \mathrm{~g}^{-1}\right)\end{array}$ &  & $\begin{array}{c}\text { Fat } \\
\left({\left.\mathrm{g} 100 \mathrm{~g}^{-1} \text { dry matter }\right)}\right.\end{array}$ & $\begin{array}{c}\text { Ash } \\
\left(\mathrm{g} \mathrm{l} 100 \mathrm{~g}^{-1} \text { dry matter }\right)\end{array}$ \\
\hline \multirow[t]{2}{*}{ AS 0} & 0 & 76.1 & 70.7 & 11.3 & 13.4 \\
\hline & 15 & 77.2 & 71.9 & 14.9 & 11.8 \\
\hline \multirow[t]{2}{*}{ AS F0.25 } & 0 & 77.7 & 64.6 & 7.2 & 17.0 \\
\hline & 15 & 76.4 & 64.5 & 7.2 & 19.9 \\
\hline \multirow[t]{2}{*}{ AS F0.43 } & 0 & 76.3 & 65.3 & 13.9 & 14.8 \\
\hline & 15 & 75.7 & 69.2 & 13.6 & 16.9 \\
\hline \multirow[t]{2}{*}{ BS M 10} & 0 & 74.6 & 55.9 & 9.1 & 15.4 \\
\hline & 15 & 78.7 & 62.4 & 14.6 & 10.3 \\
\hline \multirow[t]{2}{*}{ BS M20 } & 0 & 71.2 & 39.9 & 4.9 & 11.8 \\
\hline & 15 & 74.7 & 44.3 & 10.3 & 11.9 \\
\hline \multirow[t]{2}{*}{ BS W10 } & 0 & 74.4 & 53.5 & 10.5 & 12.1 \\
\hline & 15 & 76.2 & 56.7 & 14.7 & 8.8 \\
\hline \multirow[t]{2}{*}{ BS W20 } & 0 & 68.4 & 40.2 & 2.5 & 11.7 \\
\hline & 15 & 70.4 & 42.9 & 7.1 & 10.8 \\
\hline
\end{tabular}

\footnotetext{
*For abbreviations, see Table 1
} 




Fig. 1. Viscosity changes in blue whiting (Micromesistius poutassou Risso) ensiled by various methods. For abbreviations, see Table 1.

silages, the values obtained are too high to ensure longterm preservation. A value below 5.0 after 2 days of ensilage is recommended (Yeoh, 1979). The high $\mathrm{pH}$ values obtained may be due to the relatively low temperature used for fermentation and/or to inefficiency of the starter culture used. Several species of the genus Lactobacillus have temperature optima ranging from 30 to $40^{\circ} \mathrm{C}$ (Holt, 1994), so the use of higher fermentation temperatures could be beneficial. Also, lactic acid bacteria are known to vary in their ability to stabilise fish silage (Van Wyk and Heydenrych, 1985); the selection of efficient starter cultures is, thus, a very important step for improving the keeping quality of biological fish silage.

\section{Changes in the protein fraction}

Protein solubilisation values, as expressed by the nonprotein nitrogen content of the silages, are represented

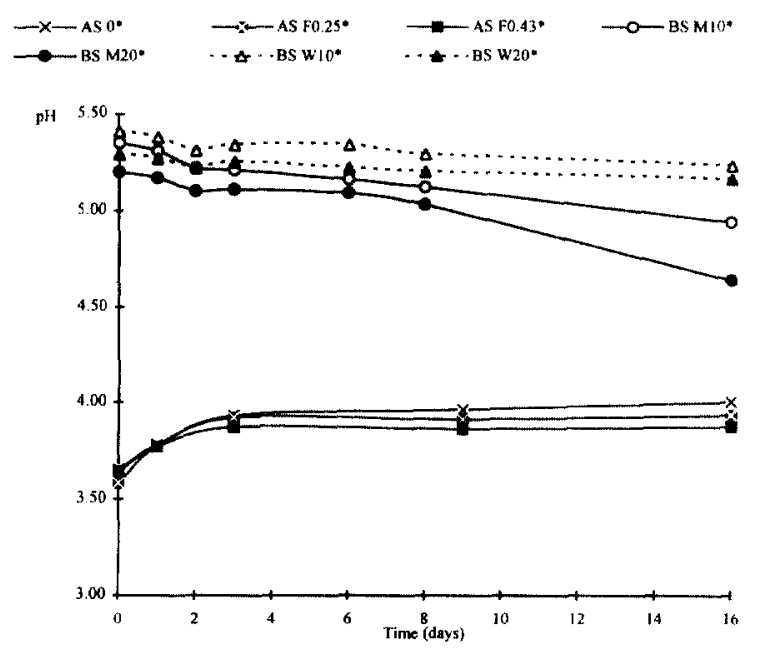

Fig. 2. $\mathrm{pH}$ changes in blue whiting (Micromesistius poutassou Risso) ensiled by various methods. For abbreviations, see Table 1. in Fig. 3. Protein solubilisation proceeded faster during the first two days (except for the biological silage with $20 \%$ added whey), but was, in general, still continuing at the end of the experiment. As expected, formaldehyde addition yielded remarkably low nitrogen solubilisation values. After 15 days of storage, the values obtained were 35 and $27 \%$ for the silages with 0.25 and $0.43 \%$ $(w / w)$ of added formaldehyde, respectively. These values do not differ considerably from the initial concentration of non-protein nitrogen (about $24 \%$ ). Ensiling by biological methods also afforded lower protein solubilisation values when compared with the acid ensilage without formaldehyde addition. Values ranging from 58 to $67 \%$ non-protein nitrogen were obtained for the biological silages, where the corresponding value for the acid silage prepared without formaldehyde addition was $84 \%$. The silage prepared by adding $10 \%$ molasses yielded much higher nitrogen solubilisation values than the other biological silages $(75 \%)$. The reasons for the lower levels of protein solubilisation in biological fish silages have not yet been established, but could be related to the different $\mathrm{pH}$ values, that could lead to differences in the activity of tissue proteases.

Figure 3 represents the evolution of total volatile nitrogen (TVBN) in blue whiting ensiled by the acid and the biological methods. TVBN measures the amount of volatile bases formed from the solubilised nitrogen derivatives. Because the solubilisation values of the silages with added formaldehyde were considerably low, total volatile nitrogen was not measured for these trials. After 15days, the acid silage with no added formaldehyde had much higher levels of TVBN


$62 \mathrm{mgN} \mathrm{N} 100 \mathrm{~g}^{-1}$ sample). Since it leads to much lower formation of TVBN, biological ensilage can be considered as advantageous when compared with the acid procedure. The formation of higher contents of TVBN may lead to a reduction in the content of amino acids

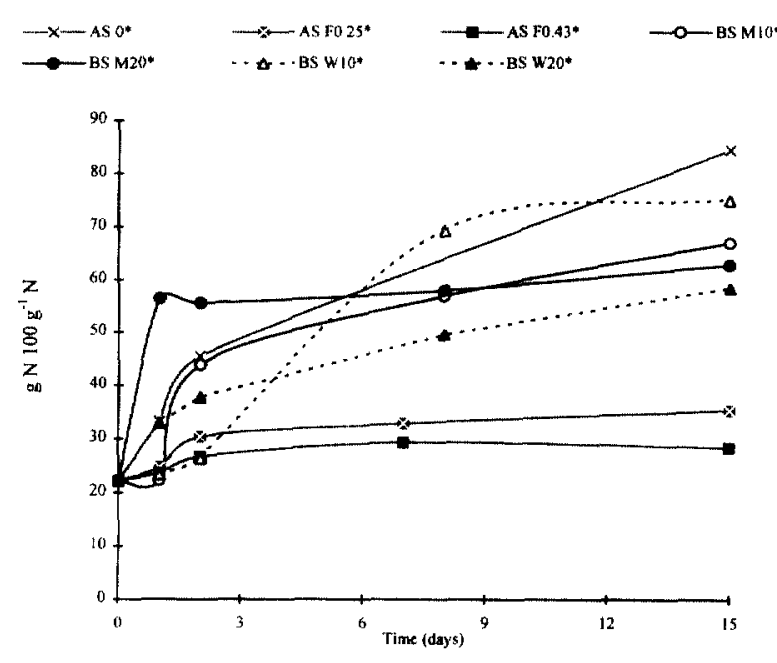

Fig. 3. Non-protein nitrogen changes in blue whiting (Micromesistius poutassou Risso) ensiled by various methods. For abbreviations, see Table 1 . 
that could have negative consequences on the nutritive value of the silage.

The amino acid composition of these samples after 15 days of storage did not show considerable differences when compared with the amino acid composition of fresh blue whiting (Table 3). The only exception was alanine in the case of the acid silage without added formaldehyde. This leads us to think that the source of the volatile nitrogen in the various types of silages tested might not be the same. We propose that, in biological silages, a small-scale deamination of the amino acids must have occurred, while in the acid silage bulk degradation of cystine may have led to the formation of a considerable amount of ammonia and/or volatile amines. While small-scale deamination of the amino acids is unavoidable and may not affect the nutritive value of the silages, heavy losses in one or a few essential amino acids will substantially change both the composition of the silage and its nutritional value (Haaland and Njaa, 1989).

It should be noted that the acid hydrolysis method used for the determination of amino acids leads to a partial destruction of cystine. All values shown in Table 3 for this amino acid are, thus, lower than its actual concentration in the silages. However, because this equally affects all of the results obtained for cystine, the comparison between different types of silages is still possible.

\section{Lipid oxidation}

The changes in peroxide values are depicted in Fig. 5. Although formaldehyde has been claimed to inhibit lipid oxidation (Haard et al., 1985), we found that the oils obtained from silages with added formaldehyde had substantially higher peroxide values than the oils from acid silage without added formaldehyde or from biological silages. Formaldehyde was found to increase the

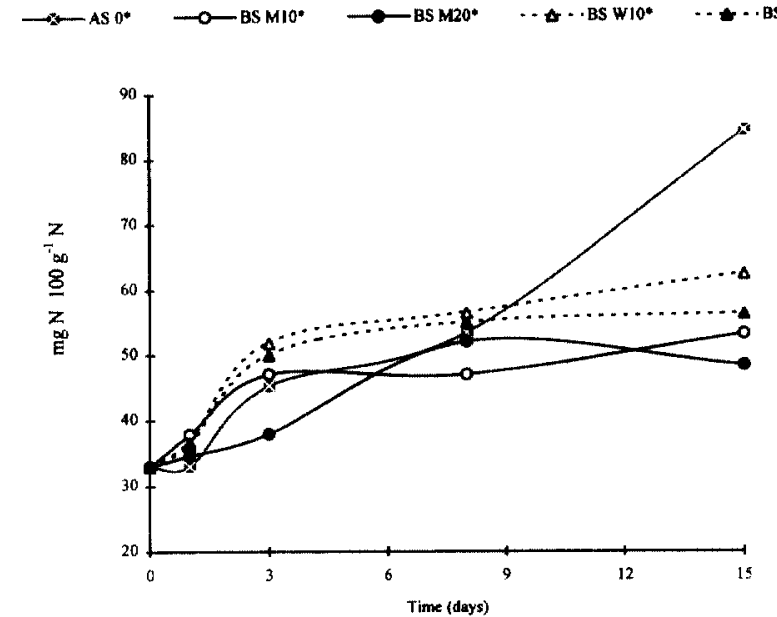

Fig. 4. Total volatile basic nitrogen changes in blue whiting (Micromesistius poutassou Risso) ensiled by various methods. For abbreviations, see Table 1.

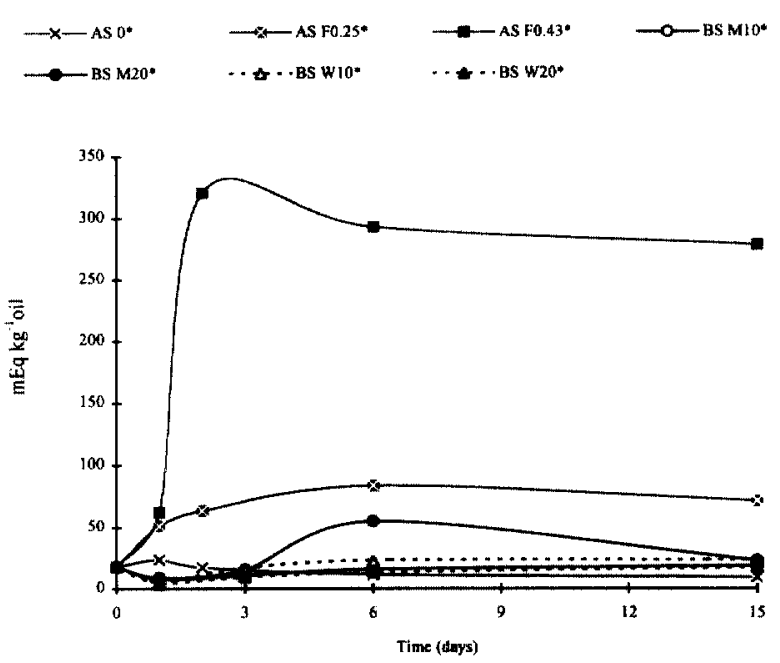

Fig. 5. Peroxide value changes in oil extracted from blue whiting (Micromesistius poutassou Risso) ensiled by various methods. For abbreviations, see Table 1.

Table 3. Concentrations of different amino acids ( $\mathrm{g}$ amino acid $16 \mathrm{~g}^{-1} \mathrm{~N}$ ) in blue whiting (Micromesistius poutassou Risso), fresh and ensiled by acid and biological methods

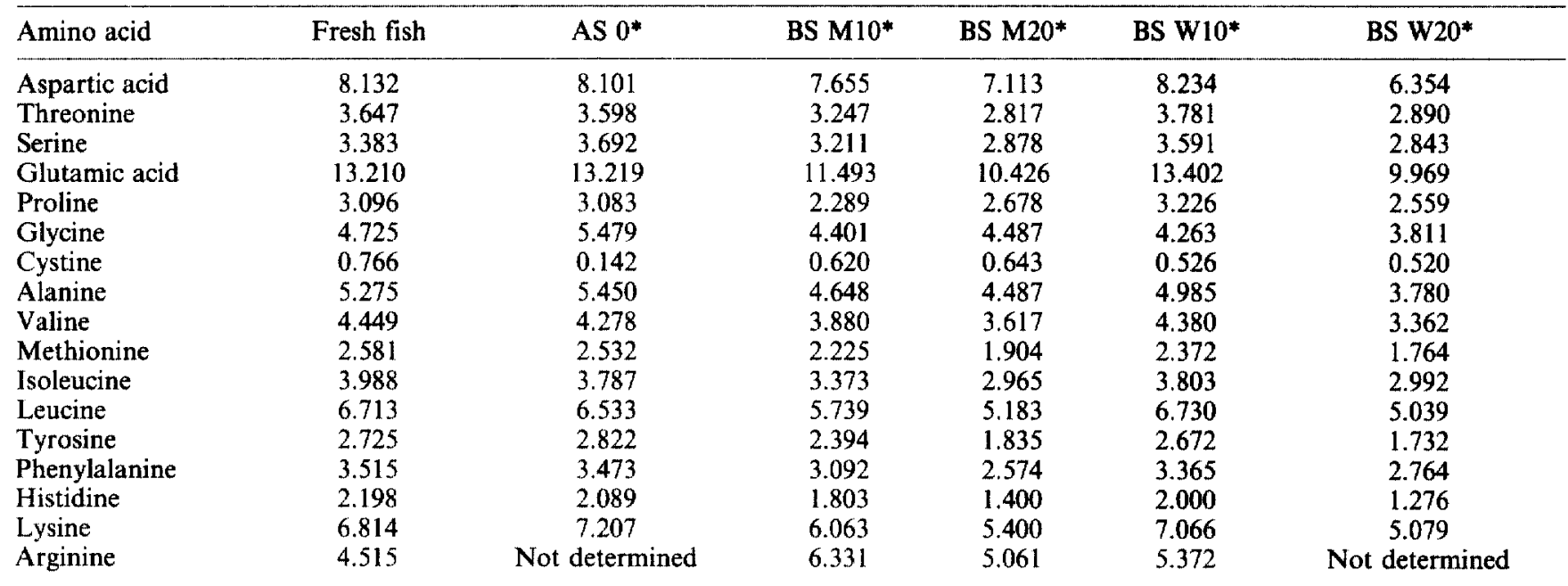

*For abbreviations, see Table 1. 
decomposition of the lipid molecules into their monomers and to notably increase lipid oxidation (Ostyakova and Kosvina, 1975) which is in agreement with our findings. It should also be mentioned that the initial peroxide values of the samples were already high (about $18 \mathrm{mEq} \mathrm{kg}^{-1}$ oil). The presence of relatively high levels of peroxides from the very beginning of the process contributes to a faster progression of the free radical chain reaction leading to increased peroxide formation, as pointed out by Hsieh and Kinsella (1989).

\section{CONCLUSIONS}

Although ensiling with formaldehyde resulted in a marked reduction in protein solubilisation, ensiling by biological methods seems to be a promising technique, as it led to lower peroxide values than ensiling with formaldehyde. It also yielded a considerable reduction in NPN and TVBN when compared with the current acid preservation technique. The biological procedure needs, however, further improvement leading to faster and more pronounced decreases in the $\mathrm{pH}$ values. The use of a higher fermentation temperature might be desirable and the choice of a suitable starter culture is of the utmost importance.

\section{REFERENCES}

Ang, J. F. and Hultin, O. H. (1989) Denaturation of cod myosin during freezing after modification with formaldehyde. Journal of Food Science 4, 814-818.

Anon. (1988) Pescado. Determinação do teor de azoto básico volátil total (A. B. V. T.). Método de Conway. Norma Portuguesa NP 2930. Instituto Português de Qualidade. Lisbon.

AOAC (1984) Official methods of Analysis of the Association of Official Analytical Chemistry, Ed. S. Williams, 14th Edition. Washington, $\mathrm{DC}$.

AOCS (1993) ed 8-53. Official Methods and Recommended Practices of the American Oil Chemists' Society, Ed. D. Firestone, 2pp., Washington, DC

Bligh, E. G. and Dyer, W. J. (1959) A rapid method of total lipid extraction and purification. Canadian Journal of Biochemical Physiology 37, 911-917.

Delort-Laval, J. (1985) Chemical treatments of oil meals. Abstract of Papers. Work Conference on Emerging Technologies in Fats and Oils Industry. (Cannes: AOCS), ed. A. R. Baldwin, pp. 218-220.

Espe, M., Haaland, H. and Njaa, L. R. (1992a) Substitution of fish silage protein and a free amino acid mixture for fish meal protein in a chicken diet. Journal of Science Food Agriculture 58, 315-319.

Espe, M., Haaland, H., Njaa, L. R. and Raa, J. (1992b) Growth of young rats on diets based on fish silage with different degrees of hydrolysis. Food Chemistry 44, 195-200.

Fagbenro, O. and Jauncey, K. (1994) Chemical and nutritional quality of fermented fish silage containing potato extracts, formalin or ginger extracts. Food Chemistry $\mathbf{5 0}$, 383-388.
Haaland, H. and Njaa, L. R. (1989) Total volatile nitrogena quality criterion for fish silage? Aquaculture 79, 311-316.

Haard, N. F., Kariel, N., Herzberg, G., Feltham, L. A. W. and Winter, K. (1985) Stabilization of protein and oil in fish silage for use as a ruminant feed supplement. Journal of Science Food Agriculture 36, 229-241.

Hassan, T. E. and Heath, J. L. (1986) Biological fermentation of fish waste for potential use in animal and poultry feeds. Agricultural Wastes 15, 1-15.

Hassan, T. E. and Heath, J. L. (1987) Chemical and nutritive characteristics of fish silage produced by biological fermentation. Biological Wastes 20, 187-201.

Holt, J. G., ed. (1994) Group 19. Regular, nonsporing Grampositive rods. Bergey's Manual of Determinative Bacteriology, pp. 565-570. Williams and Wilkins, Baltimore, MA.

Hsieh, R. J. and Kinsella, J. E. (1989) Oxidation of polyunsaturated fatty acids: mechanisms, products, and inhibition with emphasis on fish. Advances in Food and Nutrition Research 33, 233-339.

Kompiang, I. P., Arifudin, R. and Raa, J. (1980a). Nutritional value of ensilaged by-catch fish from Indonesian shrimp trawlers. In Advances in Fish Science and Technology, ed. J. J. Connell, pp. 3-9. Fishing News Books, Farnham, Surrey.

Kompiang, I. P., Yushadi and Creswell, D. C. (1980b) Microbial fish silage: chemical composition, fermentation characteristics and nutritional value. In Proceedings I. P. F. C. Workshop on Fish Silage. FAO Fish. Report No. 230, p. 38.

Lindgren, $\mathbf{S}$. and Pleje, M. (1983) Silage fermentation of fish or fish waste products with lactic acid bacteria. Journal of Science Food Agriculture 34, 1057-1067.

Lovern, J. A. (1965) Trash fish-is there money in it? World Fishing 6, 87-89.

Machin, D. H., Panigrahi, S., Bainton, J. and Morris, T. R. (1990) Performance of broiler chickens fed on low and high oil fish silages in relation to changes taking place in lipid and protein components. Animal Feed Science Technology 28, 199-223.

Ørskov, E. R. (1977) Nutritional principles and evaluation of by-products, waste products and new feeds for ruminants. Livestock Products Science 4, 165-175.

Ostyakova, E. B. and Kosvina, L. A. (1975) Changes in fractional composition of lipids of whole small fish during preservation with formalin solutions. Rybnoe Chojasjstvo 11, 81-83.

Owusu-Ansah, Y. J. and Hultin, H. O. (1987) Effect of in situ formaldehyde production on solubility and cross-linking of proteins of minced red hake muscle during frozen storage. Journal of Food Biochemistry 11, 17-30.

Potter, D., Tatterson, I. and Wignall, J. (1980) Preliminary studies of two techniques for the removal of oil from fish silage using commercial equipment. In Advances in Fish Science and Technology, ed. J. J. Connell. pp. 338-343. Fishing News Books, Farnham, Surrey.

Raa, J. and Gildberg, A. (1982) Fish silage: a review. CRC Critical Reviews in Food Science Nutrition 16, 383-419.

Verité, R., Poncet, C., Chabi, S. and Pion, R. (1977) Utilisation des tourteaux traités au formol par les vaches laitières. Annales Zootechnologie 26, 167-181.

Van Wyk, H. J. and Heydenrych, C. M. S. (1985) The production of naturally fermented fish silage using various lactobacilli and different carbohydrate sources. Journal of Science Food Agriculture 36, 1093-1103.

Yeoh, Q. L. (1979) The status of research on fish silage in Malaysia. In Fish Silage Production and Its Use, eds J. G. Disney and D. James. Papers presented at the IPFC Workshop, Jakarta, Indonesia. FAO Fisheries Report No. 230. FAO, Rome. pp. 19-23. 